\title{
Finite Element Analysis of Cross-section Optimal Combination Coefficient of Large-span Composite Floor Pipe Truss

\author{
Li-Ting CHEN ${ }^{1, a,{ }^{*}}$, Lei $\mathrm{LI}^{1, b}$, Xu-Lin SONG ${ }^{1, c}$
} \\ ${ }^{1}$ School of Civil Engineering, Chang'an University, Xi'an Shanxi 710064, China

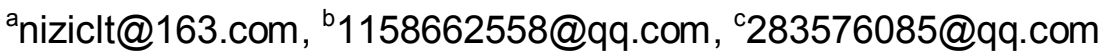 \\ ${ }^{*}$ Corresponding author
}

\begin{abstract}
Keywords: Composite Floor Pipe Truss, Ultimate Bearing Capacity, Ductility Performance, Section
\end{abstract} Optimal Combination Coefficient.

\begin{abstract}
This paper presents a finite element analysis of the failure mode,ultimate bearing capacity and ductility of composite floor pipe truss with top chord by using ABAQUS software in the aspect of bottom chord cross-section size,depth-span ratio,width-height ratio,concrete slab thickness and strength grade.Put forward the concept of cross-section optimal combination coefficient $\gamma$ and make a study about it.So as to provide a basis for the practical engineering design.
\end{abstract}

\section{Introduction}

Composite pipe truss is a new type structure which based on composite grid. All of the top chord, bottom chord and web member are composed of closed cross-section steel pipe. The truss pipe and concrete flange plates work together by connector. It has the advantages of light weight, high stiffness. In addition it has better stability and bearing capacity than pure steel truss under the condition of same steel consumption and has great prospects in all kind of large-span structure.

This paper established the model of composite floor pipe truss by using ABAQUS finite software. Analysis the failure mode, ultimate bearing capacity, ductility capacity in the aspect of bottom chord cross-section size, depth-span ratio, width-height ratio, concrete slab thickness and strength, combined with all of the calculated results of finite element models. Finally put forward the concept of cross-section optimal combination coefficient $\gamma$ and present design calculation of it. Obtain the suggested value so that can be used in the area of practical engineering design.

\section{Establishment and Validation of the Finite Element Model}

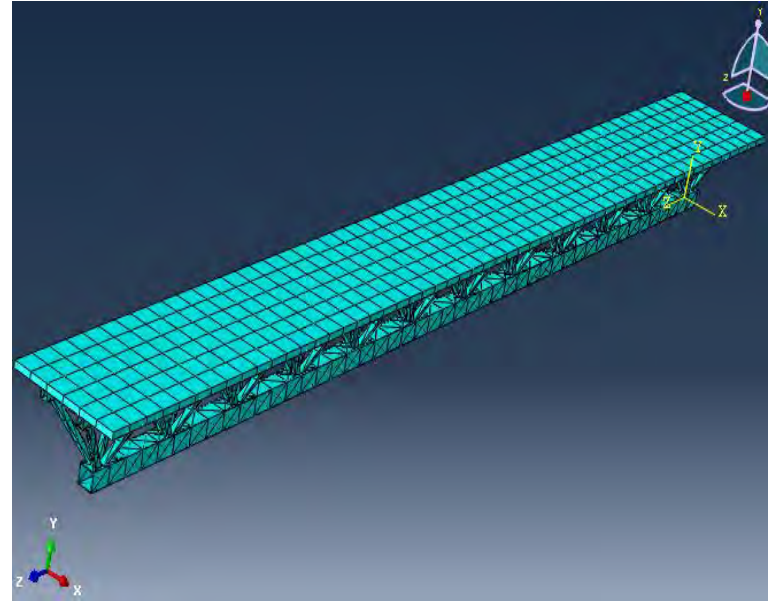

Fig. 1 The Model of Composite Floor Pipe Truss

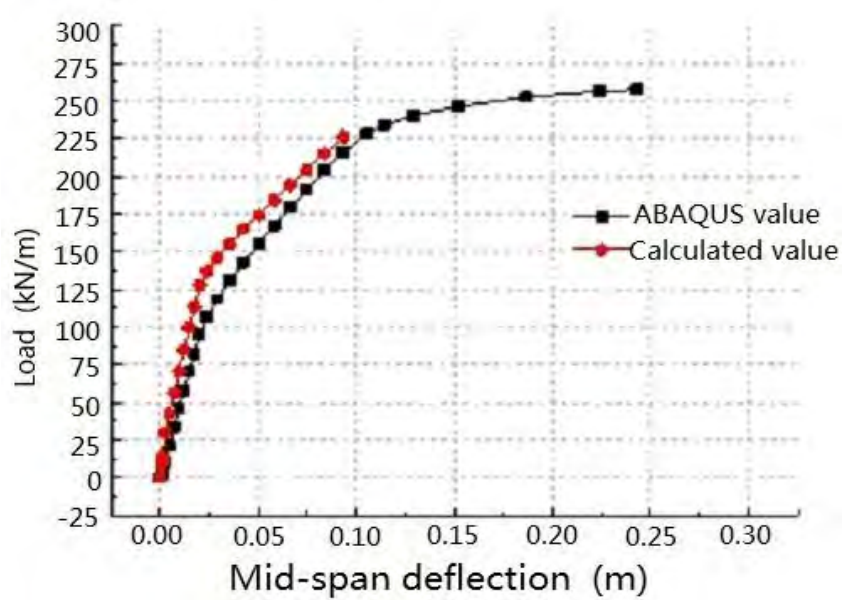

Fig. 2 The Curves of Theoretical Calculation and Finite Element Analysis

The model in this paper was established on the basis of reference [1].The span was $24 \mathrm{~m}[2]$.The diameter of distributing bars in the concrete slabs was $8 \mathrm{~mm}$ and the interval was $200 \mathrm{~mm}$.Beam cross-section chord's wall thickness was greater than or equal to the web member's wall thickness 
which was $10 \mathrm{~mm}$.As well as used Q345 steel and applied uniform load[3].The size of the model which had been selected was meeting with the requirements of reference [4].Such as the depth-span ratio, the angle between the chord and the web member. According to reference [5], the depth-span ratio adopted in this paper were $1 / 12,1 / 14,1 / 16$ respectively, the width-height ratio were $0.67,0.8$, 1.0 respectively. Concrete strength grade were C20,C30,C40,C50,C60 and its thickness were $120 \mathrm{~mm}, 140 \mathrm{~mm}, 160 \mathrm{~mm}, 180 \mathrm{~mm}, 200 \mathrm{~mm}$ respectively. The model which had been established by ABAQUS software is shown as Fig.1.

As the model mentioned above, giving the concrete slabs a thickness of $140 \mathrm{~mm}$, an effective width of $2680 \mathrm{~mm}$ [6] and valuing the concrete a C30 specification. Applying the equivalent rigidity theory, considering bending deformation and ignoring shear deformation, through the comparison of load-displacement curve which obtained from theoretical calculation and finite element analysis to validate the feasibility of the model established in this article. The comparison result show as Fig.2.As can be seen in the Fig.2 the two curves anastomose well. Therefore the model is feasible and can be used in deep analysis.

\section{The Optimization Analysis on the Basis of Cross-section Optimal Combination Coefficient}

In this paper there were 67 sets of model and they were divided into group A,B,C.Through ABAQUS software analyze the failure mode,ultimate bearing capacity and ductility in different parameters.

\section{Analysis of Failure Mode}

The composite floor pipe truss has three kinds of failure mode through the finite element analysis by using ABAQUS software.That is:(1)The bottom chord yielding first then the upper flange concrete crushed;(2)The bottom chord failure while the up flange concrete doesn't broken;(3)the upper flange concrete crushed but the bottom chord doesn't yielding. The first two failure mode is ductile failure and the last one is brittle failure.These failure mode mainly affected by the combination of the cross-section size and its steel strength,concrete slab's cross-section and its strength grade.In order to make full use of the steel and concrete it's necessary to optimize the design of cross-section.

\section{Analysis of Ultimate Bearing Capacity}

Fig. 3 shows that for different cross-section steel truss damaged before concrete when the concrete strength grade or the slab thickness greater than a certain value. So it's not obvious if simply increased the concrete strength or concrete slab thickness for improving the floor's bearing capacity.Different cross-section corresponding optimal concrete strength grade and thickness.
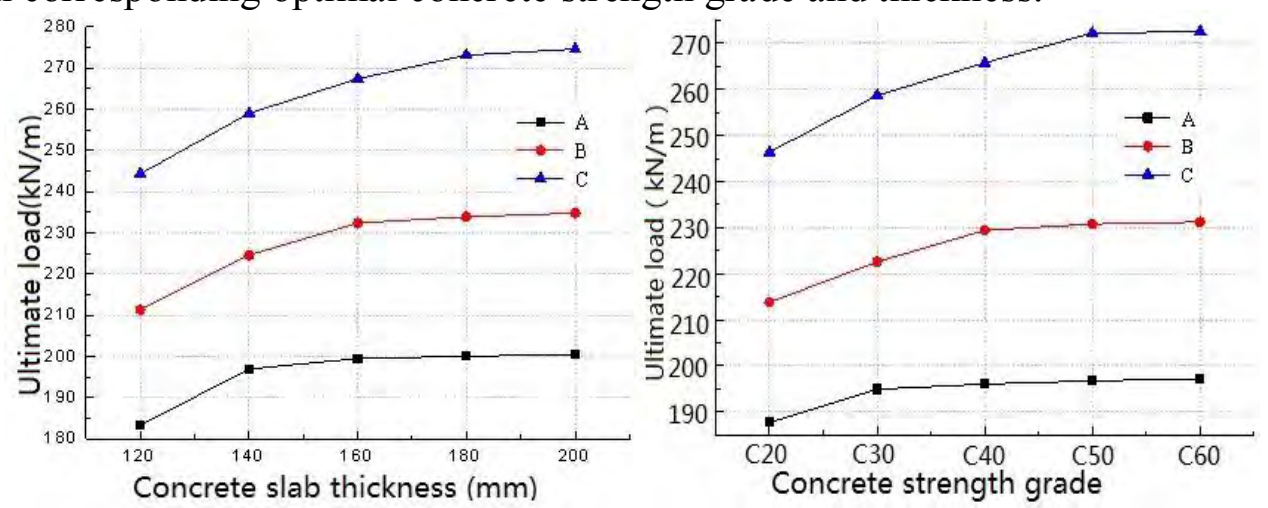

Fig. 3 Curves of Ultimate Load for Different Concrete Grade and Slab Thickness

The curves show in Fig.4 can be regarded as consisting of two line segment with different slope.There exist an obvious inflection point where the upper flange concrete and the bottom chord steel of the floor fail simultaneously. With the increase of cross-section, the ultimate bearing capacity 
improve greatly when the cross-section smaller than the optimal cross-section.But beyond the point the increase amplitude slow down.

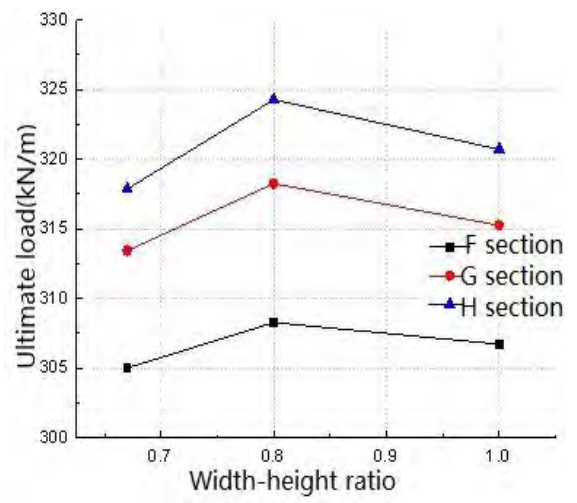

Fig. 4 Curves of Ultimate Load for Different Cross-section

Fig.5 shows that the ultimate bearing capacity of the floor increases with the increase of height span ratio. Thus under the premise of standard and construction requirements it's effectively to increase the ultimate bearing capacity through increase the depth-span ratio.

Fig. 6 shows that ratio 0.8 is the inflection point of the floor's ultimate bearing capacity.It presents an increase trend when smaller than 0.8 . When greater than 0.8 is opposite. So the ratio 0.8 is the optimal width-height ratio.

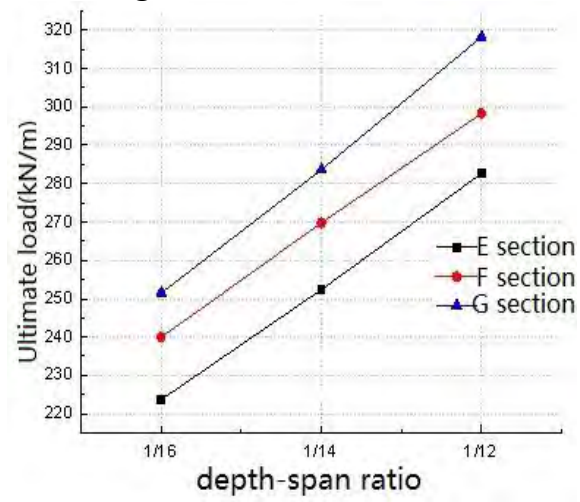

Fig. 5 Curves of Ultimate Load for Different Depth-span Ratio

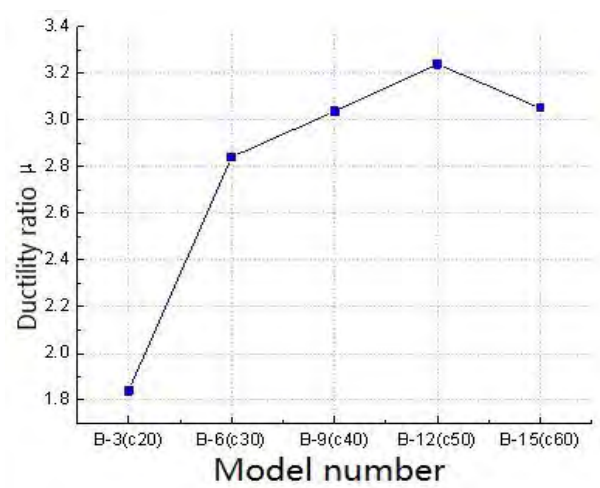

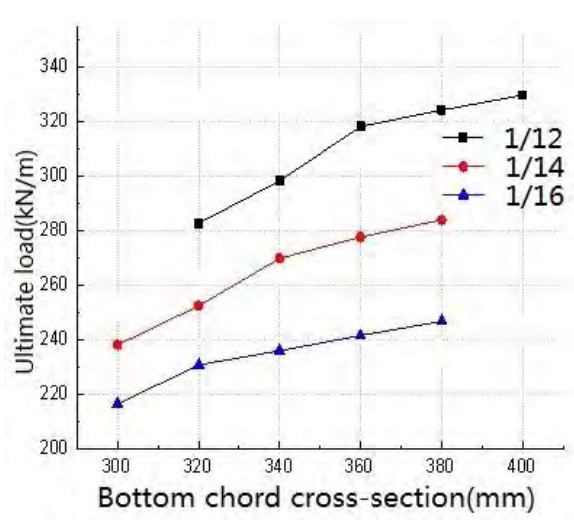

Fig. 6 Curves of Ultimate Load for Different Width-height RAnalysis of Ductility

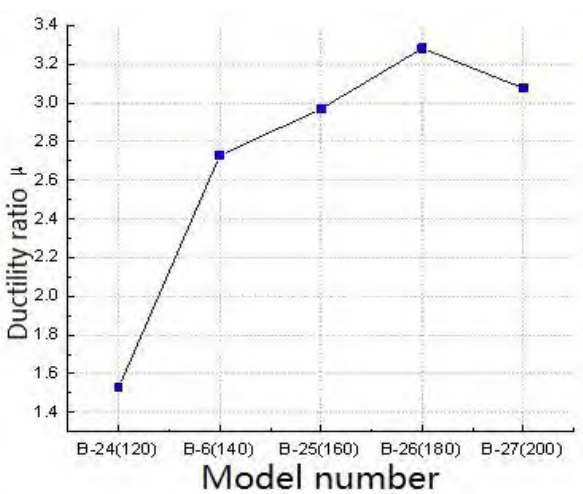

Fig. 7 Curves of Ductility with Different Concrete Strength and Thickness

Fig.7 shows that curves increase obviously before reach the peak. After the peak, curves go down with smaller amplitude. The peak point always emerges at the time of the upper flange concrete and the bottom steel chord damage almost simultaneously. So the ductility of composite floor pipe truss is related with the optimal combination of steel truss cross-section, concrete slab size and its strength, etc. 


\section{Design of Cross-section Optimal Combination Coefficient $\gamma$}

\section{The Proposition of Optimal Combination Coefficient $\gamma$}

Based on above analysis the optimal combination coefficient which proposed in this paper is expressed as Eq. 1.

$$
\gamma=\frac{f_{\mathrm{c}} A_{1}+f A_{2}}{f A_{3}}
$$

Where $f c$ and $f$ respectively represent the design strength of the upper flange concrete and the bottom steel chord; $A 1, A 2, A 3$ respectively represent the cross-section area of the upper concrete, the top steel chord and the bottom steel chord.

\section{The Calculation of $\gamma$}

According to previous results of model calculation and combine with bilinear interpolation method. The numerical results under the condition of different parameters are shown in Table 1 and Table 2.

Tab. 1 the Optimal Combination Coefficient with Different Concrete Strength and Thickness

\begin{tabular}{ccclcccc}
\hline $\begin{array}{c}\text { Num } \\
\text { ber }\end{array}$ & Parameter & $\begin{array}{c}\text { Cross } \\
\text { section }\end{array}$ & \multicolumn{1}{c}{ Failure mode } & $\begin{array}{c}f c A_{1}+f A_{2} \\
{[\mathrm{kN}]}\end{array}$ & $\begin{array}{c}f A_{3} \\
{[\mathrm{kN}]}\end{array}$ & $\begin{array}{c}\text { Combination } \\
\text { coefficient }\end{array}$ & $\gamma$ \\
\hline B-1 & C20 & $\begin{array}{c}\text { section } \\
\text { A }\end{array}$ & $\begin{array}{l}\text { concrete crushing, steel } \\
\text { pipe truss yielding }\end{array}$ & 6102 & 5635 & 1.1809 & 1.39 \\
B-4 & C30 & $\begin{array}{l}140 \mathrm{~mm} \\
\text { concrete crushing, steel } \\
\text { pipe truss breaking }\end{array}$ & 7865 & 5635 & 1.4135 & 6 \\
B-5 & $140[\mathrm{~mm}]$ & $\begin{array}{c}\text { C30 } \\
\text { concrete crushing, steel } \\
\text { pipe truss yielding }\end{array}$ & 7865 & 6627 & 1.1869 & 1.38 \\
B-21 & $160[\mathrm{~mm}]$ & $\begin{array}{c}\text { section } \\
\text { B }\end{array}$ & steel pipe truss breaking & 9181 & 6627 & 1.3967 & 6 \\
\hline
\end{tabular}

Tab. 2 the Optimal Combination coefficient with Different Depth-span Ratio and Width-height Ratio

\begin{tabular}{|c|c|c|c|c|c|c|c|}
\hline $\begin{array}{c}\text { Num } \\
\text { ber }\end{array}$ & $\begin{array}{l}\text { Width-heigh } \\
\text { t ratio }\end{array}$ & $\begin{array}{l}\text { Depth-s } \\
\text { pan } \\
\text { ratio }\end{array}$ & Failure mode & $\begin{array}{c}f_{c} A_{1}+f A_{2} \\
{[\mathrm{kN}]}\end{array}$ & $\begin{array}{c}f A_{3} \\
{[\mathrm{kN}]}\end{array}$ & $\begin{array}{l}\text { Combination } \\
\text { coefficient }\end{array}$ & $\gamma$ \\
\hline B-28 & \multirow[b]{2}{*}{0.67} & \multirow[b]{2}{*}{$1 / 12$} & steel pipe truss breaking & 11046 & 7080 & 1.5101 & \multirow[b]{2}{*}{$\begin{array}{c}1.41 \\
6\end{array}$} \\
\hline B-29 & & & $\begin{array}{l}\text { concrete crushing, steel } \\
\text { pipe truss yielding }\end{array}$ & 11046 & 7552 & 1.4024 & \\
\hline B-44 & \multirow[b]{2}{*}{0.8} & \multirow[b]{2}{*}{$1 / 14$} & steel pipe truss breaking & 11106 & 7080 & 1.5086 & \multirow{2}{*}{$\begin{array}{c}1.41 \\
7\end{array}$} \\
\hline B-45 & & & $\begin{array}{l}\text { concrete crushing, steel } \\
\text { pipe truss yielding }\end{array}$ & 11106 & 7552 & 1.4006 & \\
\hline B-64 & \multirow[b]{2}{*}{1.0} & \multirow[b]{2}{*}{$1 / 16$} & steel pipe truss breaking & 11366 & 7080 & 1.5153 & \multirow{2}{*}{$\begin{array}{c}1.41 \\
8\end{array}$} \\
\hline B-65 & & & $\begin{array}{l}\text { concrete crushing, steel } \\
\text { pipe truss yielding }\end{array}$ & 11366 & 7552 & 1.4139 & \\
\hline
\end{tabular}

Notes:(1)The top chord in above tables is square tube with $180 \mathrm{~mm}$ diameter and $10 \mathrm{~mm}$ thickness;(2)The depth-span ratio and width-height ratio in Table 1 are 1/16 and 0.67.

As can be seen from above two tables: (1) ABAQUS results and bilinear interpolation method is feasible;(2) The effect of the concrete slab thickness and its strength and the size of cross-section can be neglected in the subsequent calculation because all of the error are less than $5 \%$. The same as depth-span ratio and width-height ratio, although the value of $\gamma$ becomes greater with larger depth-span ratio and width-height ratio. 


\section{The suggestion value of $\gamma$}

Based on the previous analysis, the suggestion value of $\gamma$ is 1.430 when the width-height ratio equal or less than 0.8.In order to validate that whether the floor has good ductility under the condition of different ratio of dept-span and width-height. 4 sets of finite element model had been designed. The model parameters and the related calculation are presented in Table 3 and Table 4.

From Table 3 and Table 4 can be seen that the entire ductility coefficient of the designed model is between 3.1 and 3.3 when the value of $\gamma$ is 1.430 . That is to say the ductility is good. So it can give full play to concrete and steel truss performance if according to the value of 1.430 to design composite floor pipe truss. Not only can save the cost, but also can get good bearing capacity and ductility.

Tab. 3 The Model Parameters

\begin{tabular}{ccccccc}
\hline Number & $\begin{array}{c}\text { Depth-span } \\
\text { ratio }\end{array}$ & $\begin{array}{c}\text { Width- height } \\
\text { ratio }\end{array}$ & $\begin{array}{c}\text { Slab thickness } \\
{[\mathrm{mm}]}\end{array}$ & $\begin{array}{c}\text { Concrete } \\
\text { strength }\end{array}$ & $\begin{array}{c}\text { Slab effective } \\
\text { width }[\mathrm{mm}]\end{array}$ & $\begin{array}{c}f c A_{1}+f A_{2} \\
{[\mathrm{kN}]}\end{array}$ \\
\hline B-68 & $1 / 13$ & 0.6 & 140 & $\mathrm{C} 30$ & 2780 & 8065 \\
B-69 & $1 / 13$ & 0.75 & 140 & $\mathrm{C} 30$ & 3060 & 8626 \\
B-70 & $1 / 15$ & 0.6 & 140 & $\mathrm{C} 30$ & 2640 & 7785 \\
B-71 & $1 / 15$ & 0.75 & 140 & C30 & 2880 & 8266 \\
\hline
\end{tabular}

Tab. 4 Calculation Result

\begin{tabular}{ccccccc}
\hline Number & $f A_{3}[\mathrm{kN}]$ & $\begin{array}{c}\text { The } \\
\text { needed } \\
\text { diameter } \\
{[\mathrm{mm}]}\end{array}$ & $\begin{array}{c}\text { Practical } \\
\text { diameter } \\
{[\mathrm{mm}]}\end{array}$ & $\begin{array}{c}\text { Displacement when } \\
\text { steel yielding }[\mathrm{m}]\end{array}$ & $\begin{array}{c}\text { Limit state } \\
\text { displacement } \\
{[\mathrm{m}]}\end{array}$ & $\begin{array}{c}\text { Ductility } \\
\text { coefficient } \mu_{D}\end{array}$ \\
\hline B-68 & 5640.14 & 300.28 & 305 & 0.0717 & 0.2344 & 3.269177127 \\
B-69 & 6032.14 & 320.04 & 320 & 0.0691 & 0.2215 & 3.205499276 \\
B-70 & 5444.14 & 290.40 & 290 & 0.0804 & 0.2547 & 3.167910448 \\
B-71 & 5780.14 & 307.34 & 310 & 0.0774 & 0.2396 & 3.095607235 \\
\hline
\end{tabular}

These two tables list that all of the ductility coefficient of the designed model is between 3.1 and 3.3 when the value of $\gamma$ is 1.430 .That is to say the ductility is good. So it can give full play to concrete and steel truss performance if according to the value of 1.430 to design composite floor pipe truss. Not only can save the cost, but also can get good bearing capacity and ductility.

\section{Conclusion}

(1)Width-height ratio almost has no effect on the floor's ultimate bearing capacity. When the ratio greater or less than 0.8 the increase or decrease amplitude of ultimate bearing capacity is minimal so that can be neglected. This paper proposed the optimal width-height ratio is 0.8 .

(2)The parameter such as the steel truss cross-section, steel design strength, concrete slab thickness and its strength directly influences the floor's failure mode, bearing capacity and ductility. (3)Composite floor pipe truss shows good bearing capacity and ductility by using the suggestion optimal combination coefficient.

\section{References}

[1]Xulin Song, Long-span composite floor tube truss optimization analysis Based on the cross section under the optimal combination coefficient, D. (2014). 
[2]Ke-jian Ma, Hua-gang Zhang, Theory and Practice of New Type Architectural Space Griding Structure, first ed, China Conmunication Press, China, 2006.

[3]Tao Tao,Ruo-qian He,Bao-cheng Zhao,Finite element analysis of ultimate buckling strength in composite tube truss, J.Journal of Suzhou University of Science and Technology. 23(2010)30-33.

[4]Bao Qi,Wen-mei Kang,Design and Construction of Pipe Truss Structure,first ed, China Building Industry Press, China, 2012.

[5]Li-zhong Huang,Stability analysis of triangular three-dimentional tube truss and summary of related parameters, D.(2010)

[6]GB50017-2003, Code for Design of Steel Structures, S. China Building Industry Press, Beijing, 2006.

[7]Josef Machacek, Martin Cudejko, Longitudinal shear in composite steel and concrete trusses, J. Engineering Structures. 31(2009)55-60. 